\title{
Range contraction to a higher elevation: The likely future of the montane vegetation in
}

\section{South Africa and Lesotho}

Luke K. Bentley ${ }^{1}$, Mark P. Robertson ${ }^{2}$, Nigel P. Barker ${ }^{1,3}$

${ }^{1}$ Department of Botany, Rhodes University, Grahamstown, 6140, South Africa

${ }^{2}$ Centre for Invasion Biology, Department of Zoology and Entomology, University of Pretoria, Hatfield, South Africa

${ }^{3}$ Current address: Department of Plant and Soil Sciences, University of Pretoria, Hatfield, 0028, South Africa

\section{Acknowledgments}

We are grateful to three anonymous reviewers for their comments on this manuscript. We also thank Dr. V. R. Clark for the use of his plant occurrence database to provide independent evaluation occurrence records. Funding for this research was provided by the National Research Foundation of South Africa (Grant Unique Number GUN 2069059 to NPB), as well as the South African National Space Agency (SANSA) Earth Observation directorate. 


\section{Abstract}

Global climate change is a major challenge for the future with serious potential impacts on biodiversity. Biodiversity in mountains is particularly vulnerable as many montane species are adapted to narrow microhabitats, making them less able to adjust to a climatic change. It is considered important to investigate range changes in the South African Great Escarpment because of the high levels of biodiversity in these mountains, as well as their importance for water provision in South Africa. The current and future ranges of 46 montane plant species in South Africa and Lesotho were therefore modelled using biomod in $\mathrm{R}$, using presence points and predictor variables which included rainfall and temperature worldclim layers. The performance of distribution models produced was evaluated using the Area under the Receiver Operating Curve (AUC), True Skill Statistic (TSS), Sensitivity and Specificity. We calculated beta diversity and species richness changes between current and future climates for the group of 46 species, as well as shifts of the predicted presence region boundaries and centroids. We also analysed shifts in minimum, median and maximum elevations. Results show a contraction in species' ranges towards higher elevation as has been documented from other mountain regions around the world. These results are a cause for concern as a warming climate is decreasing the potential regions of occurrence of montane species in South Africa and Lesotho's mountainous regions of high biodiversity. This region is under a diverse range of conservation and land use management practises, and our results suggest a coordinated response to climate change is needed.

\section{Keywords}

Climate change; Drakensberg; Montane vegetation; Range contraction; Species distribution Modelling; Southern Africa 


\section{Introduction}

Global climate change is the pre-eminent challenge to humankind for the immediate future. The change that has already occurred in the global climate has led to distributional and phenological changes in many well-studied terrestrial and aquatic systems (Parmesan and Yohe, 2003; Parmesan, 2006). A latitudinal shift of 16.9 kilometres per decade towards higher latitudes has been reported in a meta-analysis by Chen et al. (2011). A recent review of predicted responses of biodiversity to climate change by Bellard et al. (2012) shows the majority of models indicate alarming biodiversity responses, the worst of which would lead to extinction rates which qualify as a sixth mass extinction. Biodiversity declines in many areas of the world are being attributed to environmental changes including climate change, alien invasion and resource consumption (Butchart et al., 2010). In their fifth assessment report, the IPCC (2014) state that unmitigated climate change is very likely to lead to increased risk of extinction for many organisms.

Biodiversity in mountainous regions is often uniquely sensitive to the impact of climate change, as many montane species are narrowly adapted to small microhabitats, making them less able to adjust to changes in climate (Beniston, 2003). As elevation increases, numerous abiotic components in mountainous areas change. These abiotic changes are described by Barry (2008): Temperature changes, on average, as a $0.6^{\circ} \mathrm{C}$ temperature decrease per 100 metres; air pressure decreases with increasing elevation; solar radiation increases with increasing elevation and precipitation shows more variable trends across elevations, with an increase in rainfall with elevation in high latitude mountain ranges, but a more complex relationship in low latitude mountain ranges. Area, cloud cover and soil quality are further abiotic factors which can vary across elevation. Owing to this abiotic variation, mountains contain very distinct vegetation belts with sharp ecotones, as well as gradients of decreasing species richness as elevation increases (Beniston, 2003; Hadley et al., 2013, McCain and Grytnes, 2010). Montane regions are home to comparatively more endemic species than other ecosystems as these species remain isolated in small, montane climatic niches high above 
the broad lowland climate belts (White, 1983; Beniston, 2003). Mountainous regions have also acted as important refugia during periods of differing climates in the past (e.g. Schönswetter et al., 2005; Wang et al., 2013; Nägele and Hausdorf, 2015).

There is mounting evidence that high elevation areas have a higher rate of warming (Pepin et al., 2015). This is attributed to the snow-albedo feedback, clouds and aerosols in the atmosphere. As snow retreats, the land surface albedo decreases as a darker surface replaces a white surface, and temperature increases. Clouds, which form higher in the atmosphere as temperatures rise, release latent heat above them, raising temperature at higher elevations. Aerosols from air pollution are concentrated at relatively low elevations and cause a surface dimming effect which decreases radiation to lower mountain slopes (Pepin et al., 2015). At higher elevations this dimming does not occur, leading to higher rates of warming. Owing to the high number of endemic species in mountains, the small, isolated climatic niches of these endemic species and the physical properties of montane regions, mountains magnify climatic changes and contain biodiversity which is highly vulnerable to a rapidly changing climate.

Upslope movement is a widely predicted theoretical response for a species to remain in its climatic niche as the climate warms (MacArthur, 1972; Peters and Darling, 1985). The coolest climatic zone at the top of a mountain is also the smallest zone, Therefore, as species move upslope their possible areas of occurrence decline in size, putting the persistence of the species at risk (Peters and Darling, 1985). Numerous studies, both repeat surveys and distribution modelling analyses support upslope migration (See appendix 1 in supplementary material).

In contrast, downslope range shifts have been noted by Platts et al. (2013) and Lenoir et al. (2010). A correlative climate modelling analysis in the Eastern Arc Mountains in east Africa, showed that many plants were predicted to move downslope based on water availability and temperature seasonality (Platts et al., 2013). In two thirds of the plants modelled, there was a downslope response in one of the mountain regions. The downslope response was particularly important in plants with a 
distribution limited by water availability and large seasonal temperature fluctuations. Possible downslope responses of plants under future climate are also noted by Lenoir et al. (2010). This was attributed to a realized niche which is considerably smaller than a fundamental niche and therefore distribution is limited by competition and not climate. In all studies on plant elevation shifts analysed by Lenoir et al. (2010), which included 824 species, $25 \%$ of species were predicted to move lower, with $65 \%$ predicted to move higher, while $10 \%$ were not predicted to change their positions.

Species distribution modelling has an important role to play in assessing current and future distributions of plant species. Correlative species distribution models exploit species-environment relationships in order to make distribution predictions. They correlate species occurrence records with chosen predictor variables to create a spatial 'envelope' of occurrence (Pearson and Dawson, 2003). Climate has a strong controlling influence on where plants can grow, with global ecosystems generally corresponding well with a precipitation/heat balance in an environment (Woodward, 1987). In the current study, climatic predictor variables were used to model the species' bioclimatic envelopes. The key assumption made here is that plants in South Africa's mountainous regions are ultimately limited by temperature and rainfall. Pearson and Dawson (2003) consider this assumption to be is easier to make when modelling plant distribution at a coarse scale over a large area than at a fine scale over a small area. Climate change is predicted to cause temperatures to rise by as much as $6^{\circ} \mathrm{C}$ by the end of the century at the current trajectory, as well as a general drying across South Africa (Haensler et al., 2011). The impacts of these climatic changes on vegetation are important to explore.

The study of future vegetation distribution in the mountains of South Africa and Lesotho is highly relevant because of the importance of this region in terms of ecosystem services (most notably water supply) and its endemic biodiversity (Taylor et al., 2016). The Drakensberg mountain range in particular, and the Great Escarpment in general, is a critical supplier of water for South Africa (Nel, 2009). There are a number of centres of plant endemism associated with the Great Escarpment, 
such as in the Winterberg-Amatole, Sneeuberg, the north-eastern Drakensberg and the main Drakensberg, as well as several officially recognised Important Bird Areas (Cowling and Hilton-Taylor, 1997; Matthews et al., 1993; Carbutt and Edwards, 2004; Clark et al., 2009; Clark et al., 2014; Marnewick et al. 2015).

The aim of this study is to predict changes in species richness patterns, species assemblage changes, average elevation and geographic range of a selection of montane plant species occurring in the Great Escarpment of South African and Lesotho. Using this selection of species, we also compare these changes among different plant growth forms.

The species selected are not expected to shift much geographically as they are already situated over the highest elevation areas of the region. They are also not predicted to move much across the latitudinal gradient, because they occur in montane areas which have steep elevation-based climatic gradients allowing them to track climatic changes more easily by changing elevation. Based on the largely supported upslope movement response of montane plants to climate change found in a range of previous studies, (Appendix 1 in Supplementary Material) and the types of predictor variables being used, the geographical ranges of species selected here are predicted to contract towards a small area, centred on the Maloti-Drakensberg region under future climate scenarios. The change in diversity for the plant assemblage between current climate and future climate is expected to show a high level of diversity change at low elevation, with the high elevation Maloti-Drakensberg region expected to show a low level of diversity change.

\section{Methods}

\section{Study area}

The study area covers the mountain ranges making up the Great Escarpment of South Africa and Lesotho (Figure 1). A Great Escarpment, defined as a mountainous region which runs parallel to a coast separating a coastal plain from a central plateau (Ollier, 1985; Partridge and Maud, 1987; 
Birkenhauer, 1991). These mountains are the dominant feature in South Africa's landscape and vary in elevation from about 2000 to over $3000 \mathrm{~m}$ in the high Drakensberg (McCarthy and Rubidge, 2005).

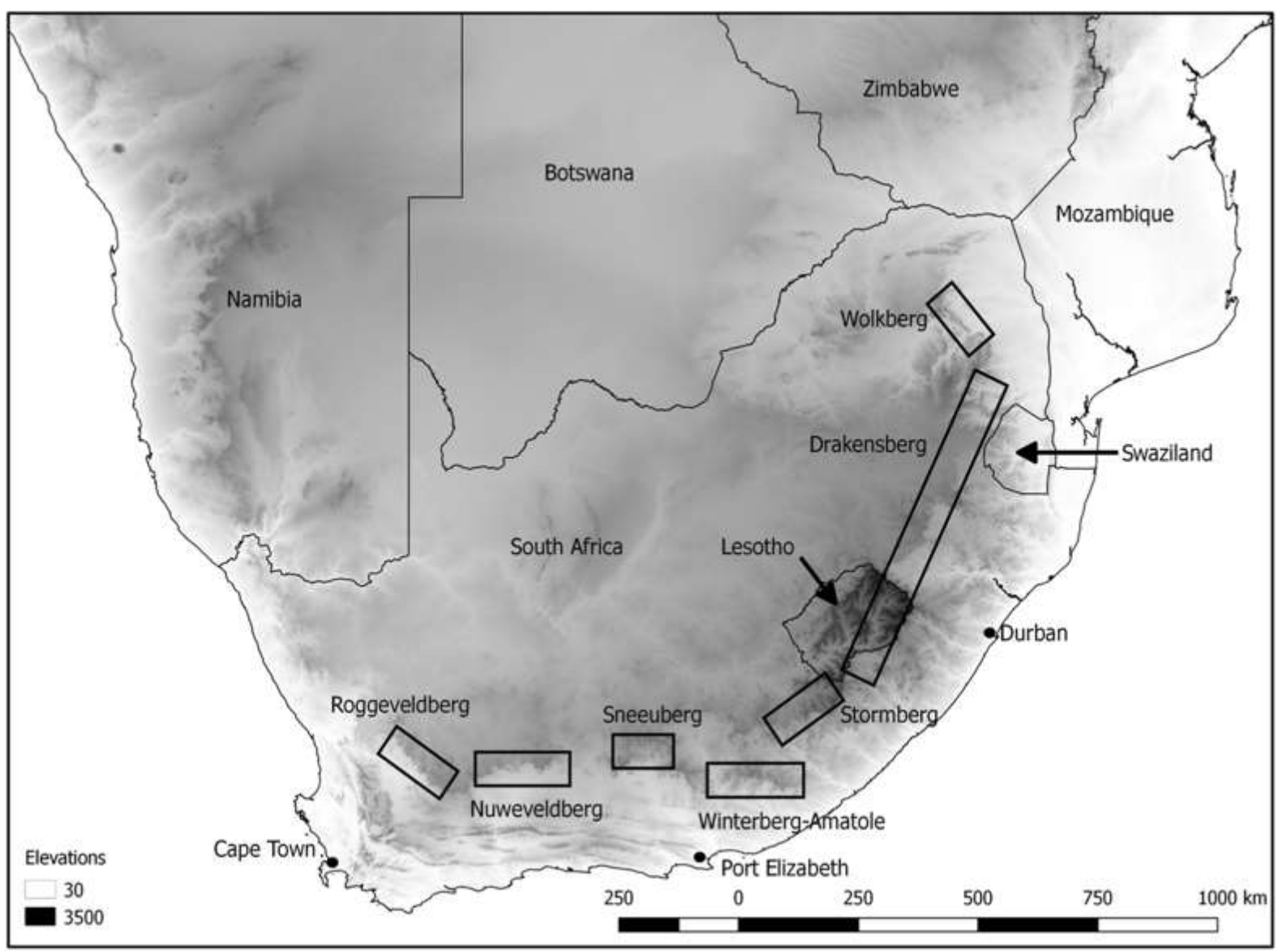

Fig. 1. South African map on a digital elevation model (DEM) with mountain ranges in the research area indicated as black rectangles. All mountain ranges are part of the Great Escarpment, which separates the coastal plain from the central plateau. The Sneeuberg, southern Drakensberg and north-eastern Drakensberg are proposed centres of plant endemism

The climate over the Great Escarpment is highly varied, ranging from humid in the east and northeast to arid in the west (Clark et al., 2011a). The rainfall regime is summer rainfall in the Soutpansberg, Wolkberg and Drakensberg, through to the eastern Nuweveldberg (largely convectional and orographic rainfall), with all year rainfall in the rest of the Nuweveldberg and winter rainfall in the Roggeveldberg (largely frontal and orographic rainfall).

The plant life of the Great Escarpment comprises many species endemic to narrow sections of the total mountain range. The north-eastern Drakensberg (in north-eastern South Africa) has a high 
number of plant families with species and whole genera endemic to this north-eastern region (Matthews et al., 1993). The southern escarpment region incorporates the Nuweveldberg, Roggeveldberg, Sneeuberg, Winterberg-Amatola and Stormberg (see Fig. 1). The Sneeuberg was identified as a centre of endemism, with 46 endemic and near-endemic species (Clark et al., 2009). The major biomes in the Sneeuberg include Grassland, Forest, Albany thicket and Nama-Karoo. In the Nuweveldberge, only $0.5 \%$ of species are endemic (Clark et al., 2011b), and the vegetation contains elements of Succulent Karoo and Grassland biomes (Clark et al., 2011b). The Roggeveldberge comprise vegetation with Fynbos, Succulent Karoo and Nama-Karoo elements (Clark et al., 2011c). The Winterberg-Amatola range contains 1877 species, with an endemism percentage of 1.9\%, and incorporates the Grassland, Albany Thicket, Savanna, Forest, Nama-Karoo and Eastern temperate freshwater wetland biomes (Clark et al., 2014). The Drakensberg Alpine Centre is $40000 \mathrm{~km}^{2}$ and supports over 2800 native taxa (Carbutt and Edwards, 2004). Angiosperms constitute $89 \%$ of surveyed plant species and $16 \%$ of these are endemic.

\section{Species and data selection}

We selected a group of species which is representative of mountainous vegetation of the study area. Occurrence records were selected from the PRECIS database, a southern African plant database containing more than 900000 records covering the area south of the Kunene and Limpopo rivers (SANBI, 2009). Distribution records for species in this database are available at 15 minute spatial resolution (i.e. quarter degree grid cells). Plant species were selected to ensure representation of the following growth forms: suffrutex, geophyte, fern, herb, graminoid, shrublet, succulent and tree. An approximately equal number of species were selected per growth form, and covers the range of montane plant growth forms. This enables us to obtain an unbiased account of the response of montane vegetation to climate change and to test if there are any differing responses among growth forms. A total of 46 plant species which meet these criteria and that had adequate data available (more than 20 occurrence records) were selected from the database. A second independent dataset 
to be used for independent evaluation for 20 of the selected species was also included. A minimum of five occurrence records per species was deemed necessary for an independent dataset to be useful. The independent occurrence records were provided by V. R. Clark and are situated in the southern escarpment between 20.2 and $26.8^{\circ} \mathrm{E}$ and 30.9 and $32.8^{\circ} \mathrm{S}$ from the Stormberg west to the Roggeveldberg (Figure 1). They are therefore situated away from the Drakensberg (the focal region for training occurrences) making them a good independent evaluation dataset (Table 1).

Table 1. Species selected for this study, their growth form, habitat and the number of records used in distribution modelling. Superscript numbers indicate literature citations, as follows: 1=Pooley (2005); $2=$ Hilliard and Burtt (1987); 3= Crouch et al. (2011); 4=Pooley (2003); 5=pers. comm. V.R. Clark; 6=Notten (2011); 7=Hyde et al. (2015a); 8=Foden and Potter (2005a); 9=Hyde et al. (2015b); 10=Lawrence (2002); 11=Foden and potter (2015b); 12=Hoare (n.d.); 13=Foden and Potter (2011).

\begin{tabular}{|c|c|c|c|c|c|}
\hline Species & $\begin{array}{l}\text { Growth } \\
\text { form }\end{array}$ & Family & Habitat & $\begin{array}{l}\text { Occurrence } \\
\text { records }\end{array}$ & $\begin{array}{c}\text { Independent } \\
\text { occurrence } \\
\text { records }\end{array}$ \\
\hline Ajuga ophrydis & Suffrutex & Lamiaceae & Grassland $^{1}$ & 204 & 9 \\
\hline Alchemilla woodii & Suffrutex & Rosaceae & Disturbed areas ${ }^{2}$ & 57 & \\
\hline Aristea woodii & Geophyte & Iridaceae & Grassland $^{1}$ & 40 & \\
\hline $\begin{array}{l}\text { Asplenium adiantum-nigrum } \\
\text { var. adiantum-nigrum }\end{array}$ & Fern & Aspleniaceae & $\begin{array}{l}\text { Montane grassland at base of } \\
\text { boulders }^{3}\end{array}$ & 88 & 16 \\
\hline $\begin{array}{l}\text { Asplenium trichomanes } \\
\text { subsp. quadrivalens }\end{array}$ & Fern & Aspleniaceae & $\begin{array}{l}\text { Cliffs and boulder scree in high } \\
\text { altitude grassland }{ }^{3}\end{array}$ & 41 & 17 \\
\hline Berkheya purpurea & Herb & Asteraceae & Steep grassy mountain slopes ${ }^{1}$ & 25 & \\
\hline Bromus speciosus & Graminoid & Poaceae & $\begin{array}{l}\text { Moist slopes in mountain } \\
\text { grassland }^{2}\end{array}$ & 25 & \\
\hline Buddleja loricata & Shrub & Buddlejaceae & Afromontane forest margins ${ }^{4}$ & 34 & \\
\hline Cheilanthes quadripinnata & Fern & Sinopteridaceae & $\begin{array}{l}\text { Ecotone between montane } \\
\text { grassland and forest }{ }^{3}\end{array}$ & 121 & 21 \\
\hline Cliffortia ramosissima & Shrublet & Rosaceae & Dry Fynbos ${ }^{5}$ & 46 & 11 \\
\hline Crassula dependens & Succulent & Crassulaceae & $\begin{array}{l}\text { Rocky outcrops in Karoo / } \\
\text { Grassland }^{1}\end{array}$ & 100 & 20 \\
\hline
\end{tabular}




\begin{tabular}{|c|c|c|c|c|c|}
\hline Crassula natalensis & Succulent & Crassulaceae & $\begin{array}{l}\text { Mountain grassland among } \\
\text { rocks }^{1}\end{array}$ & 28 & \\
\hline Dierama robustum & Geophyte & Iridaceae & High altitude grassland ${ }^{4}$ & 59 & 9 \\
\hline Erica algida & Shrublet & Ericaceae & Grassy slopes ${ }^{1}$ & 42 & \\
\hline Erica frigida & Shrublet & Ericaceae & $\begin{array}{l}\text { Frequent on cliffs and steep } \\
\text { slopes }^{4}\end{array}$ & 41 & \\
\hline Euphorbia pulvinata & Succulent & Euphorbiaceae & Rocky grassland ${ }^{1}$ & 56 & \\
\hline Euryops annae & Shrub & Asteraceae & Mountain grassland ${ }^{6}$ & 75 & 17 \\
\hline Festuca caprina & Graminoid & Poaceae & $\begin{array}{l}\text { Boulder beds and mountain cliff } \\
\text { faces }^{2}\end{array}$ & 92 & \\
\hline Festuca costata & Graminoid & Poaceae & $\begin{array}{l}\text { Marshy areas in montane } \\
\text { grassland }^{2}\end{array}$ & 75 & 8 \\
\hline $\begin{array}{l}\text { Geranium } \\
\text { wakkerstroomianum }\end{array}$ & Herb & Geraniaceae & $\begin{array}{l}\text { Sheltered areas around rocks and } \\
\text { forest margins }{ }^{1}\end{array}$ & 95 & \\
\hline Gladiolus saundersii & Geophyte & Iridiaceae & Rocky mountain slopes ${ }^{1}$ & 27 & \\
\hline Haplocarpha nervosa & Suffrutex & Asteraceae & Marshy grassland ${ }^{7}$ & 43 & \\
\hline Helichrysum herbaceum & Suffrutex & Asteraceae & Grassland $^{1}$ & 115 & \\
\hline Helichrysum sutherlandii & Shrublet & Asteraceae & Cliffs and rocky outcrops ${ }^{1}$ & 45 & \\
\hline Hypoxis multiceps & Geophyte & Hypoxidaceae & Grassland $^{1}$ & 64 & \\
\hline Indigofera burchellii & Suffrutex & Fabaceae & $\begin{array}{l}\text { High altitude grassland and } \\
\text { Karoo }^{8}\end{array}$ & 22 & 8 \\
\hline Kniphofia caulescens & Geophyte & Asphodelaceae & $\begin{array}{l}\text { Marshy grassland on mountain } \\
\text { slopes }^{1}\end{array}$ & 39 & \\
\hline Leucosidea sericea & Tree & Rosaceae & $\begin{array}{l}\text { Forest margins and drainage lines } \\
\text { in mountain grassland }{ }^{4}\end{array}$ & 139 & 10 \\
\hline Lobelia preslii & Herb & Lobeliaceae & $\begin{array}{l}\text { Mountain grassland and rocky } \\
\text { gullies }^{4}\end{array}$ & 43 & \\
\hline Lotononis sericophylla & Shrublet & Fabaceae & $\begin{array}{l}\text { Rocky areas and streams in } \\
\text { disturbed areas }{ }^{1}\end{array}$ & 40 & 14 \\
\hline Merxmuellera macowanii & Graminoid & Poaceae & $\begin{array}{l}\text { Stream banks in high altitude } \\
\text { grassland }^{4}\end{array}$ & 55 & 9 \\
\hline Mohria nudiuscula & Fern & Anemiaceae & $\begin{array}{l}\text { Seasonally moist montane } \\
\text { grassland }^{9}\end{array}$ & 40 & 7 \\
\hline Moraea spathulata & Geophyte & Iridaceae & Open grassland, among rocks ${ }^{1}$ & 109 & 9 \\
\hline Pelargonium zonale & Herb & Geraniaceae & Forest margins and stony slopes ${ }^{10}$ & 80 & \\
\hline
\end{tabular}




\begin{tabular}{|c|c|c|c|c|c|}
\hline Polygala gymnoclada & Herb & Polygalaceae & Grassland $^{11}$ & 48 & \\
\hline Polygala rhinostigma & Herb & Polygalaceae & Mountain grassland ${ }^{1}$ & 27 & \\
\hline Polystichum monticola & Fern & Aspidaceae & Rocks in stream gullies ${ }^{4}$ & 59 & 14 \\
\hline Protea subvestita & Tree & Proteaceae & $\begin{array}{l}\text { Boulder beds and gullies } \\
\text { protected from fire }\end{array}$ & 67 & \\
\hline Schoenoxiphium lanceum & Graminoid & Cyperaceae & Fynbos $^{5}$ & 20 & 12 \\
\hline Senecio asperulus & Suffrutex & Asteraceae & Grassland and Karoo ${ }^{13}$ & 105 & 19 \\
\hline Senecio barbatus & Suffrutex & Asteraceae & Marshy grassland ${ }^{1}$ & 32 & \\
\hline Senecio rhomboideus & Suffrutex & Asteraceae & Grassland, rocky outcrops ${ }^{1}$ & 31 & \\
\hline Tetrachne dregei & Graminoid & Poaceae & High altitude grassland $d^{12}$ & 102 & 6 \\
\hline Zaluzianskya glareosa & Herb & Scrophulariaceae & Boulderbeds and rock sheets ${ }^{2}$ & 20 & \\
\hline Zaluzianskya ovata & Herb & Scrophulariaceae & $\begin{array}{l}\text { Partly shaded cliff faces and } \\
\text { slopes }^{1}\end{array}$ & 37 & 6 \\
\hline Zaluzianskya spathacea & Herb & Scrophulariaceae & Damp grassy slopes ${ }^{2}$ & 38 & \\
\hline
\end{tabular}

Occurrence points from each species were removed if they were in the ocean, had $(0,0)$ coordinates, were an obvious outlier far from the mountainous region of South Africa or were duplicates in a quarter degree grid cell. This was done in R version 3.1.3 (R core team, 2015) using the biogeo package in $\mathrm{R}$ (Robertson et al., 2016).

\section{Predictor variables}

The climate change predictions were produced using dynamically downscaled projections for southern Africa from the globally modelled Global Climate Models (GCMs) (Engelbrecht et al., 2011). These projections use known southern African meteorological phenomena and incorporate this into a forecast to get a more precise prediction.

The 19 bioclimatic predictor variables were produced with rainfall and temperature data using the dismo package in R (Hijmans et al., 2015). The data for current climate are an average obtained from records collected between 1971 and 2005. The future distribution changes were modelled to midcentury (an average climate of 2040-2080), based on the A2 climate change scenario which is a 
relatively high greenhouse gas emission scenario from the IPCC's $4^{\text {th }}$ assessment report (AR4) (Department of Environmental Affairs, 2013).

\section{Modelling algorithms}

Biomod is an R package which can be used to create model ensembles using multiple modelling algorithms (Thuiller et al., 2014). The ensemble method made use of five algorithms which were shown by Elith et al. (2006) to perform well in a comparative study, these include: Maximum Entropy (MaxEnt), Generalised Additive Models (GAM), Boosted Regression Trees (BRT or GBM in biomod2), Multiple Additive Regression Splines (MARS) and Generalised Linear Models (GLM).

\section{Pseudo-absence creation}

Biomod2 (Thuiller et al., 2014) ensemble runs require absences, but pseudo-absences are used if real absences are not available. Pseudo-absences are inferred absences when no real absences are available. Pseudo-absence selection that is neither too far nor too close to the presence points and that is environmentally stratified is recommended by Chefaoui and Lobo (2008) and Barbet-Massin et al. (2012). Koppen-Geiger climate zones (Koppen, 1936) were used to define regions from which pseudo-absence records were drawn, following the approach used by Webber et al. (2011). The environmental space was produced by overlaying all occurrence records with the climate zones and selecting the zones which overlap with the occurrences. Pseudo-absences for the Biomod model runs were created in $\mathrm{R}$ version 3.1 .3 by selecting all 15 minute grid cells in the delimited background that did not represent presences for each species.

Seven initial climatic predictor variables were selected and included: The maximum temperature of the warmest month (Bio 5); the minimum temperature of the coldest month (Bio 6); annual precipitation (Bio 12); precipitation of the wettest quarter (Bio 16); precipitation of the driest quarter (Bio 17); precipitation of the warmest quarter (Bio 18) and precipitation of the coldest quarter (Bio 19). Values were extracted from the seven predictor variables for each of the 46 
species. Pearson correlations were calculated for all pairs of variables for all species (Hodd et al., 2014; Ihlow et al., 2014). Bio 18 and Bio 19 were removed for all species in Biomod because they were highly correlated with many of the other predictors.

\section{Ensemble models}

R version 3.1.3 was used to run biomod2 to create ensemble models for each species using the five different modelling algorithms specified above. Each algorithm was cross-validated five times for the ensembles. 100 pseudo-absences were randomly selected from within the background mask produced. Clamping masks were included for both current and future model runs as is recommended by Elith et al. (2010) to stop the algorithms from projecting environmental suitability to environmental values on which the model was not trained.

Models were run to both current (1971-2005) and future climate (2040-2080). Presences and pseudo-absences were trained to masked current climate predictor variables. Distribution models were projected to unmasked raster layers for both current and future climate for each of the six Regional Climate Models (RCMs). A total of 25 models were considered for the ensemble for each $\mathrm{RCM}$ and, of those 25 , only models with an AUC greater than 0.8 were selected. Final ensemble models were produced by taking a mean of the six models produced for each of the six RCMs. The final outputs included current and future probability of occurrence predictions and current and future presence/absence predictions for each species. The threshold for the presence/absence maps was set at $2^{\text {nd }}$ percentile presence. Future presence/absence maps were produced for full dispersal and no dispersal scenarios. Full dispersal is the assumption that between current and future climate projections of species' distributions, a modelled species is able to disperse to all climatically suitable regions predicted under future climate. No dispersal is the assumption that no dispersal will occur in future. 


\section{$\underline{\text { Model evaluation }}$}

Cross-validation and independent dataset approaches were used for model evaluation. A five-fold cross-validation was performed on models for all species produced using Biomod. For a subset of 20 of the species for which independent presence records were available, a model evaluation using these independent records was performed. For both evaluation approaches the Area Under the Receiver Operating Curve (AUC), True Skill Statistic (TSS), Sensitivity and Specificity were calculated on models calibrated with variables representing the current climate ( $R$ version 3.1.3).

A total of 150 AUC, TSS, Sensitivity and Specificity scores were considered for each species from the final Biomod ensembles. These were the scores across all component models which resulted in the final ensemble. Any model runs with AUC scores lower than 0.8 were discarded and a mean final AUC, TSS, Sensitivity and Specificity score was then determined for each species.

For each species for the independent evaluations for Biomod models, AUC scores were calculated on the ensemble models using the PresenceAbsence package (v. 1.1.9) in R (Freeman, 2012). The pseudo-absences were randomly selected to fall within the mask and equal the maximum number of presences for the independent occurrence datasets which was 21.

Independent TSS, Sensitivity and Specificity scores were calculated on the final binary ensemble model for current climate for the Biomod results. Pseudo-absences were selected in the same manner as for the calculation of AUC scores. For each of the 20 species evaluated, the independent occurrence records and pseudo-absences were overlaid on each species' distribution model. TSS, Sensitivity and Specificity were then calculated based on true and false positives and negatives for each species. 


\section{Species richness and composition}

Species richness for current climate and future climates were attained using the binary ensemble models for each species. These were added together to get the number of species predicted per grid cell in both current and future climate (for full and no dispersal scenarios).

To investigate the change in species composition between current and future time periods, beta diversity metrics were calculated using the betapart package (Baselga et al., 2013) in R version 3.1.3. Beta diversity was determined from current climate to future climate using the final ensemble binary maps for current climate and a full and no dispersal future, as were used for the species richness analysis. The beta diversity outputs included three metrics: total beta diversity $\left(\beta_{\text {sor }}\right)$, species turnover $\left(\beta_{\text {sim }}\right)$ and the nestedness index $\left(\beta_{\text {sne }}\right)$. The total compositional variation between the species assemblages is represented by $\beta_{\text {sor }}$ which includes both species turnover and nestedness patterns (Bishop et al., 2015). Species turnover is described by $\beta_{\operatorname{sim}}$ and indicates how a species assemblage has changed with outside species replacing formerly established species in an area (Bishop et al., 2015). The nestedness index is the difference between $\beta_{\text {sor }}$ and $\beta_{\text {sim }}$ and is described by the metric $\beta_{\text {sne. }}$. This refers to assemblage nestedness in its compositional change from current climate to future climate (Bishop et al., 2015). In a climate change context, highly nested areas are regions of highest species loss.

In order to quantify elevational range shift, we calculated the minimum, median, maximum and total elevational range for each species using values extracted from a digital elevation model for all presence cells in species range projections based on current and future (full and no dispersal) models. We calculated range size for each species by counting the number of grid cells predicted to be suitable in species range projections.

To quantify geographic range shifts we compared the position of the centroid of the range of each species between current and future projections. The centroid for each range map was calculated 
using the gCentroid function in the rgeos package (Bivand et al., 2016). We also compared the $y$ coordinates of the northern and southern boundaries, and the $x$ coordinates of the eastern and western boundaries of the presence regions between current and future.

To examine total species' change under climate change, the declines in the 46 study species' range sizes were plotted against the geographic shift distances of the centroids of their presence regions. The decline in range size was determined by calculating the proportion by which the number of gridcells decreased from current climate to future climate.

\section{Results}

\section{Species richness}

For current climate, a region of high species richness was evident over the high elevation regions of Lesotho (Fig. 2a, b). Other areas of high richness in current climate were noticeable to the west of Port Elizabeth and to the north-east of Cape Town. Under future climate, the region of high richness contracted towards Lesotho (Figure 2c, d), while surrounding low elevation regions had lower species richness than for current climate. The other regions of relatively high richness just west of Port Elizabeth and east of Cape Town also showed similar trends of species richness contraction towards high elevation in the future. There was a marginally greater contraction towards high elevation regions under the no dispersal assumption (Figure $2 \mathrm{~d}$ ).

\section{Beta diversity}

The biggest differences in species composition between current and future (beta diversity score) occurred in the low elevation regions of south-western, central and north-eastern South Africa surrounding the high elevation area for both full and no dispersal (Figure 3a, d). Under the no dispersal assumption, compositional differences were marginally smaller (lower beta diversity scores) in some low elevation regions (Figure 3d). Species turnover, which explains how much a species assemblage has changed, with new foreign species replacing local species, was highest in the 
a

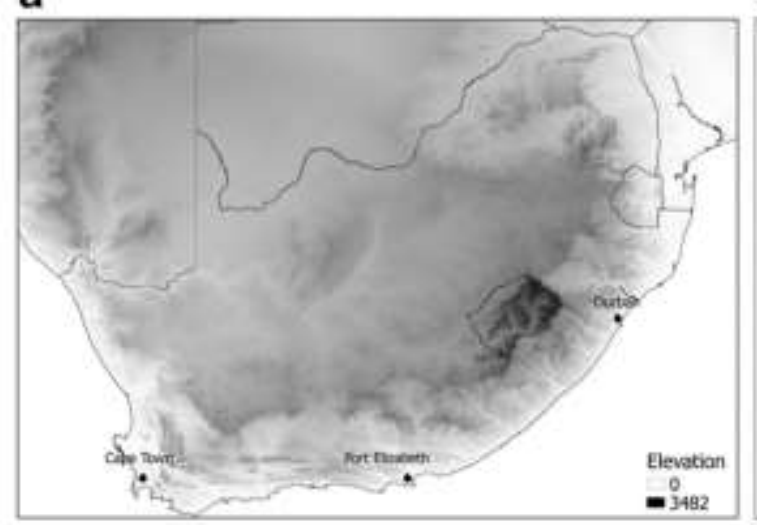

C

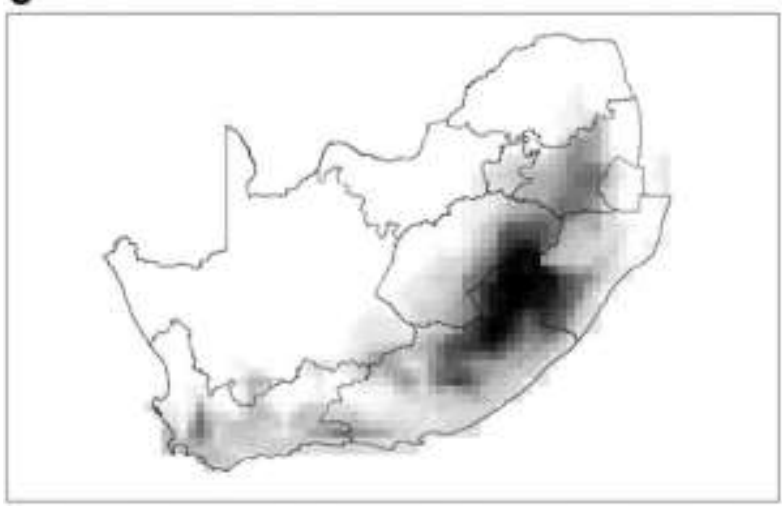

b

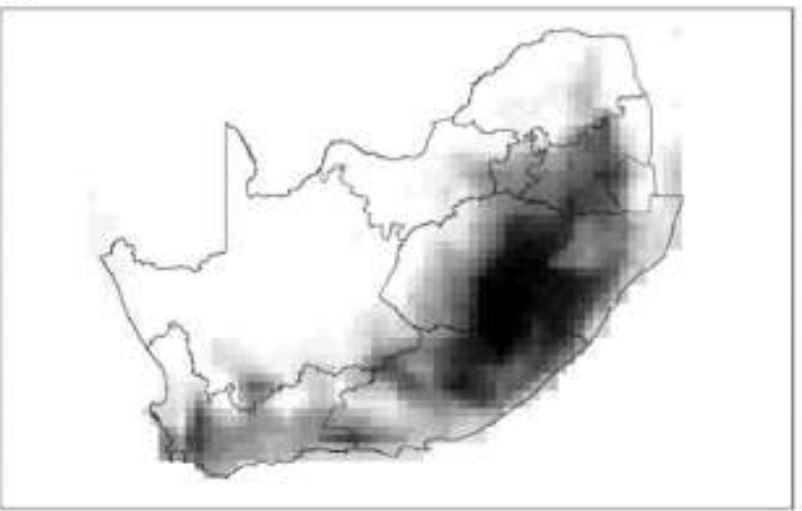

d

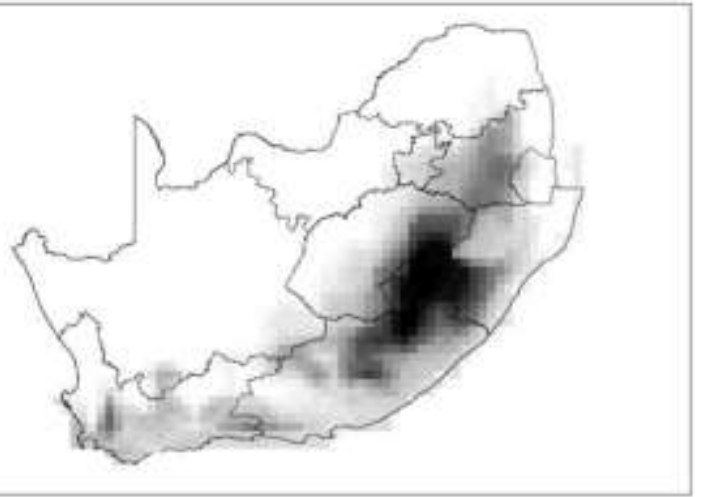

Fig. 2. $\mathbf{a}$ is a map showing the locations of the occurrence points used. The other maps show predicted species richness patterns for the 46 modelled species for b current climate (1971-2005), c future climate (2040-2080) with full dispersal and $\mathbf{d}$ future climate with no dispersal. For the species richness maps, black shaded regions denote high richness, with lighter grey to white denoting lower richness

south-western, central and north-eastern regions of the country (Figure 3b). When assuming no dispersal, species turnover does not take place, leading to lower total species compositional difference under the no dispersal assumption. Nestedness scores were high in the low elevation regions surrounding the Drakensberg highlands, meaning there was high species loss from those regions from current to future climate (Figure 3c, e). Under no dispersal (Figure 3e), nestedness values were higher than under full dispersal (Figure 3c) in the low elevation regions. Nestedness appeared to be more important than turnover in explaining total compositional differences between current and future climates, which can be attributed to range contraction of species towards higher elevation. 
a

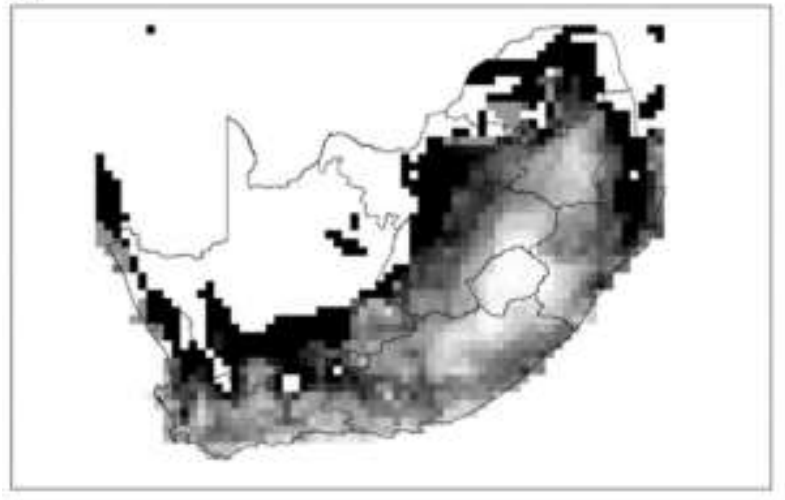

C

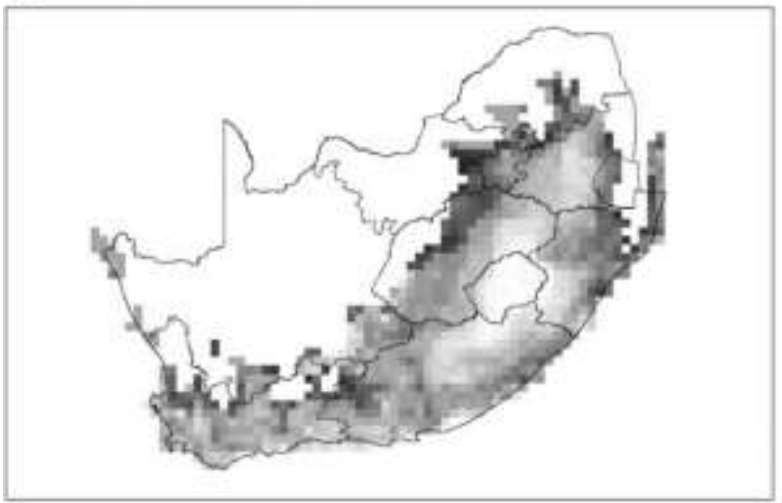

e

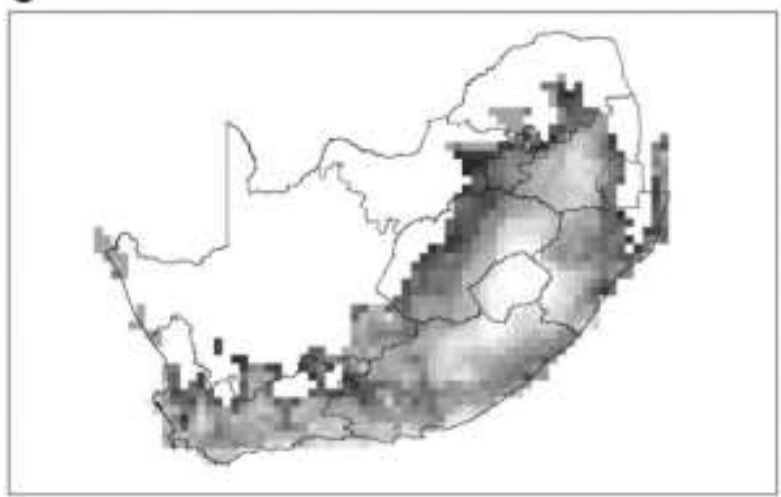

b

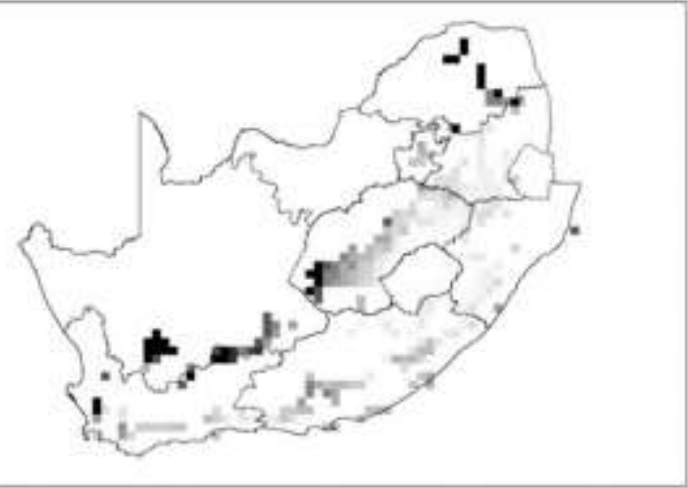

d

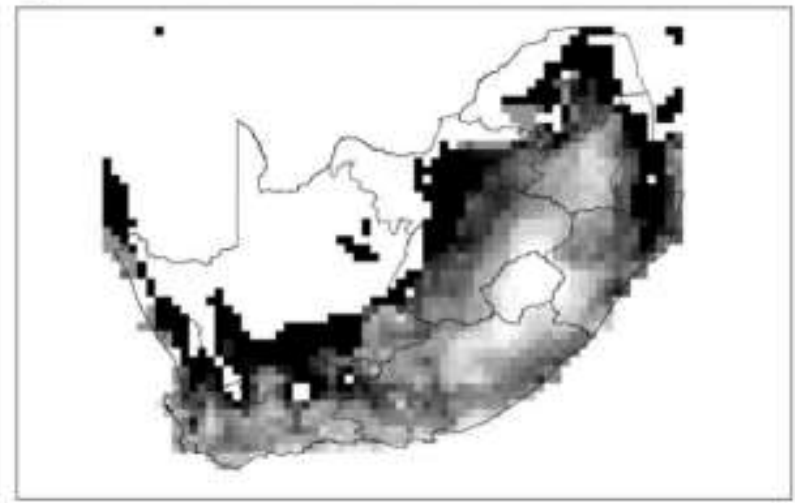

Fig. 3. a Total beta diversity, $\mathbf{b}$ turnover and $\mathbf{c}$ nestedness results for the full dispersal assumption, and $\mathbf{d}$ total beta diversity and e nestedness results for the no dispersal assumption for all 46 modelled species. Dark denotes a higher value and all indices are measured between 0 and 1

\section{Model evaluation}

The independently evaluated models had significantly lower sensitivity scores in comparison to the models that were evaluated using cross-validation $(W=92, p<0.001$; Figure $4 a)$. The independently evaluated models did not have significantly different specificity scores compared to the models with 
cross-validated evaluation $(t=1.9149, \mathrm{df}=19.3, \mathrm{p}=0.07$; Figure $4 \mathrm{~b})$. TSS scores of independently evaluated models were significantly lower than those for the cross-validated models ( $W=839, p<$ 0.001; Figure 4c). Lastly, the independently evaluated models had significantly lower AUC scores in comparison to models evaluated using cross-validation $(t=5.39, d f=19.74, p<0.001$; Figure $4 d$ ). Models performed well in terms of the evaluation on dependent data. Model performance was poorer when evaluated on independent data, but with median scores of 0.5 for TSS and 0.85 for AUC, model performance was still moderate to good (Buckland et al. 2014; Vorsino et al., 2014; Hodd et al., 2014).
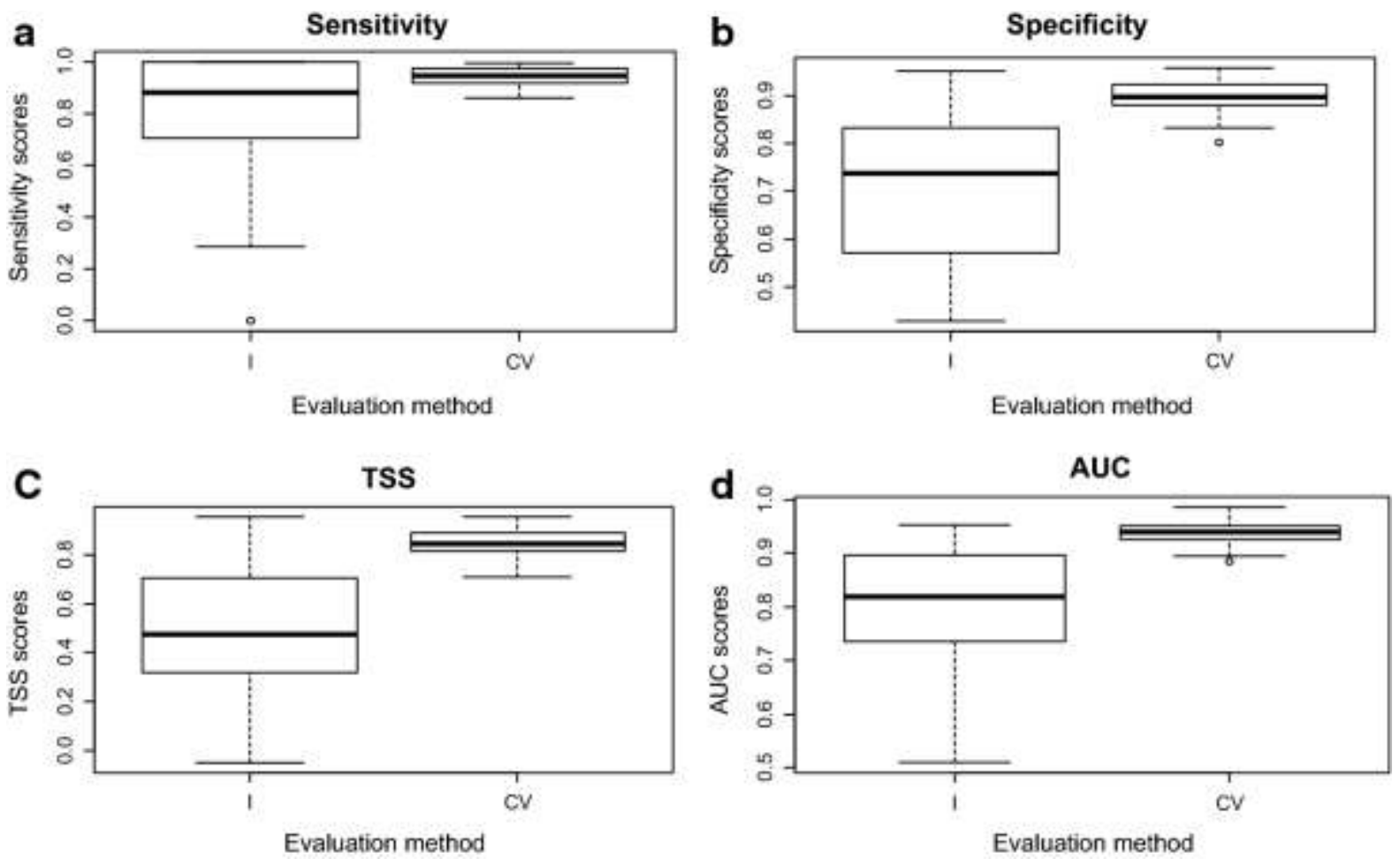

Fig. 4. Results of model evaluation for models that were evaluated using independent evaluation (I) and cross validation (CV) for a sensitivity, $\mathbf{b}$ specificity, $\mathbf{c}$ TSS and $\mathbf{d}$ AUC. The independent model evaluation was done for 20 species and the cross validated evaluation was done for all 46 species

\section{Changes in species ranges}

There was a significant shift of species towards higher elevation with relative frequency of elevations up to $1200 \mathrm{~m}$ decreasing in the future and the relative frequency of elevations above $1500 \mathrm{~m}$ increasing in future under the full dispersal scenario $(D=0.113, p<0.001)$. Elevation minima were significantly higher (Kruskal-Wallis $=8.127, \mathrm{p}=0.02$ ), midpoints significantly higher (Figure 5a; 
Kruskal-Wallis $=23.314, \mathrm{p}<0.001)$ and range sizes significantly smaller (Figure 5b; Kruskal-Wallis = $7.675, p=0.02$ ) between current climate and future climates. Elevation maxima were not significantly different between current and future climate (Kruskal-Wallis $=0.132, p=0.94)$. There was a significantly smaller predicted geographical extent under future climate in comparison to current climate (Kruskal-Wallis $=27.683, p<0.001$; Figure $5 c$ ), with future climate with no dispersal and future climate with full dispersal scenarios having similar trends for geographical extent (Figure 5c).

a

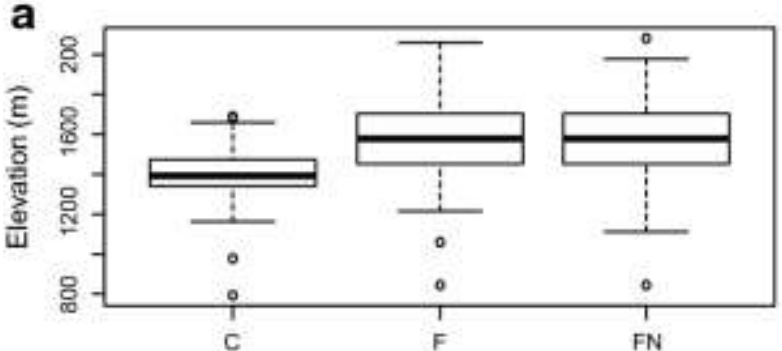

C
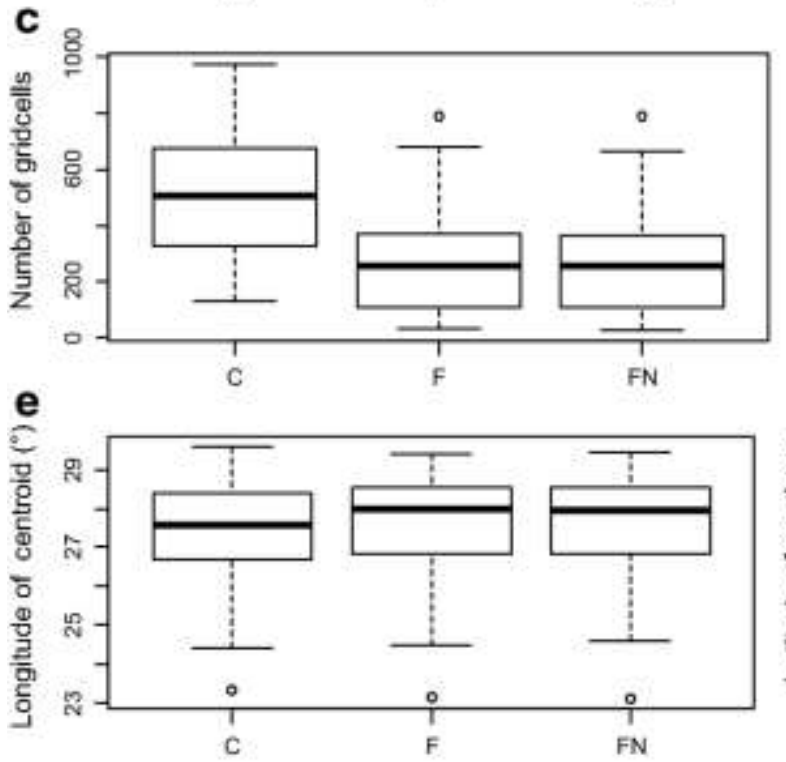

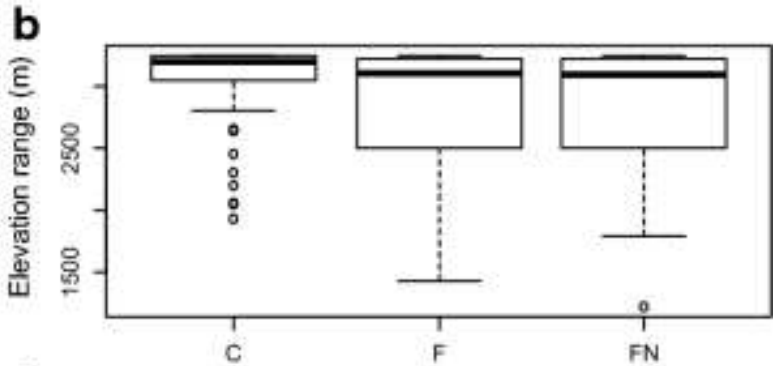

d
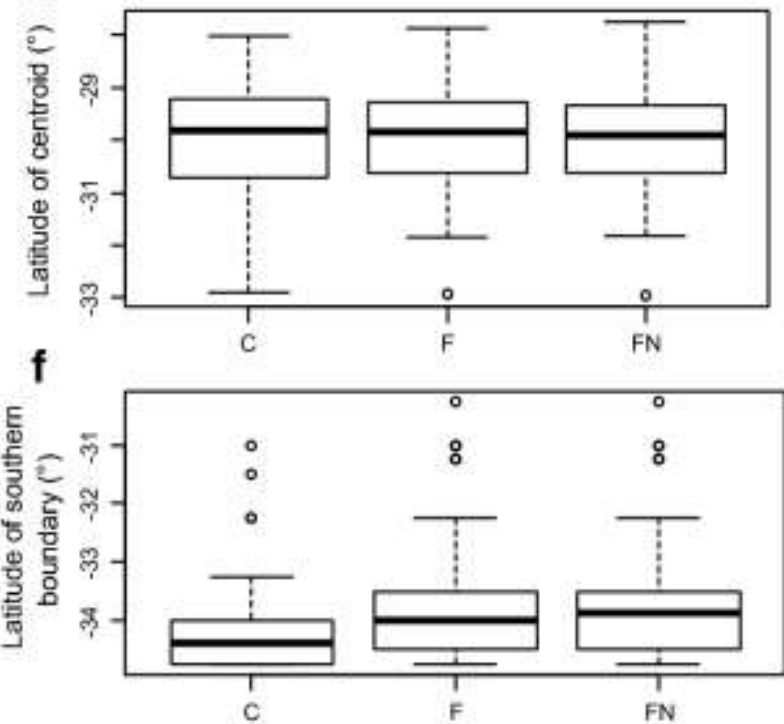

Fig. 5. The change in a median elevations, $\mathbf{b}$ elevation ranges, $\mathbf{c}$ geographical range sizes measured as the number of gridcells predicted as present, $\mathbf{d}$ the latitudes of the centroids of the regions predicted as present, $\mathbf{e}$ the longitudes of the centroids of the regions predicted as present and $f$ the latitudes of the southern boundaries of the regions predicted as present. $C$ current, $F$ future, $F N$ future no dispersal

There was no significant difference in the latitudes (Kruskal-Wallis $=0.137, p=0.93$; Figure $5 d$ ) or longitudes (Kruskal-Wallis $=1.351, p=0.51$; Figure $5 e$ ) of the centroids of the current and future 
ranges. The southern boundaries of the species' ranges were significantly further north (KruskalWallis $=42.24, p<0.001$; Figure $5 f$ ) and the northern boundaries were significantly further south (Kruskal-Wallis $=41.124, p=0.002$ ) under the future climate scenario in comparison to current climate. The eastern boundaries of the species' ranges were significantly further west (Kruskal-Wallis $=37.39, p<0.001$ ) and the western boundaries significantly further east (Kruskal-Wallis $=42.615, p=$ 0.001) under future climate.

\section{Range changes by growth form}

There was no significant difference in range declines $(F=1.346, p=0.252)$ or range shifts (KruskalWallis $=5.89, p=0.66)$ among different growth forms between current and future climates. Figure 6 shows the range changes against the declines in range size for different growth forms. Species in the top right of the figure are likely to experience the most change as a result of a changing climate and are candidate species for monitoring. Of the 46 species, 28 were predicted to experience a range size decline of greater than $40 \%(0.4)$ and 15 of greater than $60 \%(0.6)$, with seven of the species predicted to have a range shift of greater than $100 \mathrm{~km}$ and 20 of greater than $100 \mathrm{~km}$. 


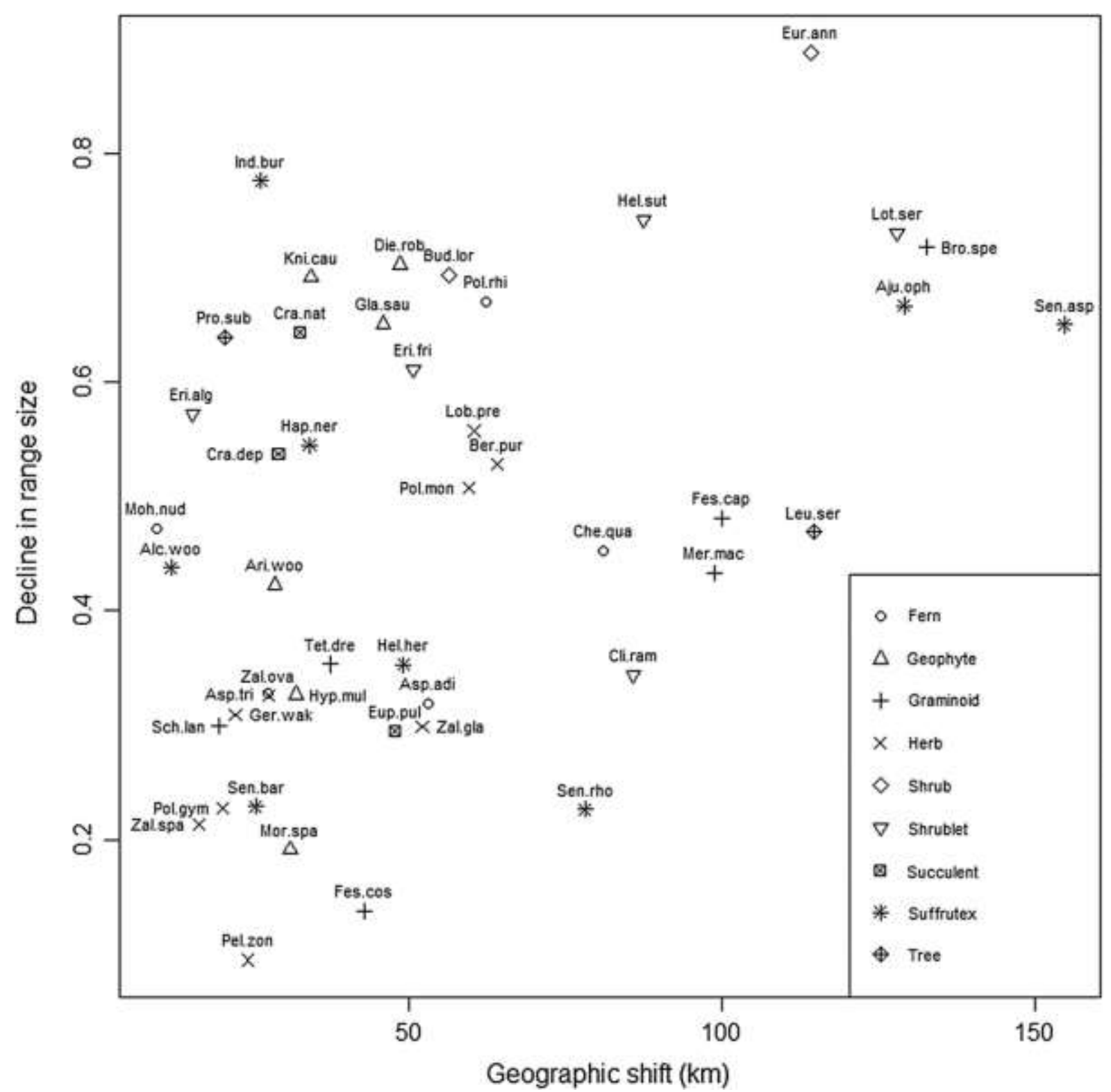

Fig. 6. The geographic shift of the centroid of the regions of predicted occurrence versus the decline in range size. The decline in range size is measured as the proportion by which the species range sizes decrease between current and future. Species in the top right are predicted to experience the most total change as a result of climate change, while those in the bottom left, the least. Species abbreviations are as follows: Aju oph-Ajuga ophrydis; Alc woo-Alchemilla woodii; Ari woo-Aristea woodii; Asp adi-Asplenium adiantumnigrum var. adiantum-nigrum; Asp tri-Asplenium trichomanes subsp. quadrivalens; Ber pur-Berkheya purpurea; Bro spe-Bromus speciosus; Bud lor-Buddleja loricata; Che qua-Cheilanthes quadripinnata; Cli ram-Cliffortia ramosissima; Cra dep-Crassula dependens; Cra nat-Crassula natalensis; Die rob-Dierama robustum; Eri alg-Erica algida; Eri fri-Erica frigida; Eup pul-Euphorbia pulvinata; Eur ann-Euryops annae; Fes cap-Festuca caprina; Fes cos-Festuca costata; Ger wak-Geranium wakkerstroomianum; Gla sauGladiolus saundersii; Hap ner-Haplocarpha nervosa; Hel sut-Helichrysum sutherlandii; Hel Her-Helichrysum herbaceum; Hyp mul-Hypoxis multiceps; Ind bur-Indigofera burchellii; Kni cau-Kniphofia caulescens; Leu ser-Leucosidea sericea; Lob pre-Lobelia preslii; Lot ser-Lotononis sericophylla; Mer mac-Merxmuellera macowanii; Moh nud-Mohria nudiuscula; Mor spa-Moraea spathulata; Pel zon-Pelargonium zonale; Pol gym-Polygala gymnoclada; Pol mon-Polystichum monticola; Pol rhi-Polygala rhinostigma; Pro sub-Protea subvestita; Sch lan-Schoenoxiphium lanceum; Sen asp-Senecio asperulus; Sen bar-Senecio barbatus; Sen rho-Senecio rhomboideus; Tet dre-Tetrachne dregei; Zal gla-Zaluzianskya glareosa; Zal ova-Zaluzianskya ovata; Zal Spa-Zaluzianskya spathacea 


\section{Discussion}

\section{Assessment of model performance}

Overall, model performance is good when occurrence points are evaluated to current climate projections using the TSS and AUC performance metrics with both independent and training occurrences (Buckland et al. 2014; Vorsino et al., 2014; Hodd et al., 2014). TSS, sensitivity and AUC model performance indicators are all significantly lower for the evaluation with independent data in comparison to the evaluation with the cross validation procedure. This is to be expected as independent evaluation uses an independent dataset, not the occurrence record dataset used to train the models, so an independent dataset is likely to show poorer model performance as the models have not been trained to this dataset.

\section{Change in elevation and geographical ranges}

Analyses make it clear that species' ranges are predicted to contract in the future to higher elevations rather than shifting horizontally across the landscape. On average, the minimum and median elevations across the species group are projected to increase significantly under future climate. On average, the elevation ranges across which the species occur are also expected to decrease significantly under future climate. In contrast, the maximum elevations of projected species' ranges are not projected to change significantly in future. This is because 42 of the 46 modelled species are already at the highest elevation in the study area. The average latitude of the northern boundaries of the 46 study species is projected to shift significantly south and the southern boundary significantly north, with the average longitude of the eastern boundary projected to shift significantly west and the western boundary significantly east. This is consistent with a range contraction across the selection of species and this is shown in the significantly smaller projected species ranges under future climate in comparison to current climate (Figure $5 c$ ). The average 
latitudes and longitudes at the centroids of the projected areas of occurrence, however, do not shift significantly between current and future, highlighting a range contraction rather than a range shift.

There is very little difference between the projections under full dispersal and no dispersal which corresponds with a range contraction. A projected range shift across the landscape is likely to lead to new areas being colonised by a species which would create a large difference in full dispersal and no dispersal projections. When using correlative species distribution models, unpredictability in the rate at which dispersal occurs is problematic as it leads to a lag in the movement of a species to its newly projected niche of occurrence (Guisan and Thuiller, 2005). This causes a climatic debt as species do not immediately occupy areas that become suitable as the climate changes (Devictor et al., 2012). In the current study where range contraction is prominent, there is little influence of a dispersal lag, allowing for greater confidence in our projections.

The graphical outputs for species richness and beta diversity show this range contraction from current climate to future climates. There is a large region of high richness over Lesotho and directly north, east and south-west of Lesotho, as well as small regions of relatively high richness in the south-west of South Africa under current climate and these regions decline in size under future climate. Beta diversity predictions show large compositional differences at the low elevation regions surrounding the Maloti-Drakensberg highlands centred over Lesotho and KwaZulu-Natal. Nestedness scores show high levels of species loss in low elevation areas surrounding Lesotho. The plant assemblages in these regions will be represented by a subset of the species occurring in the core region. Nestedness scores seem to be the main component accounting for the compositional difference between current and future climates. High species turnover is predicted in parts of South Africa's south-west, the centre of the country and in the north-east of South Africa. Turnover did not occur in the high elevation, main Drakensberg region because this is the high elevation refugium for these species i.e. a location supporting the relictual populations for previously more widespread 
species (Keppel et al., 2012). Turnover, being a replacement of some species with other species, only occurred in low elevation regions.

Our results correspond strongly with previous modelling and survey studies on mountain biota (Appendix 1 of Supplementary Material), which show a general trend of montane species moving to higher elevations and experiencing range contractions.

\section{$\underline{\text { Caveats }}$}

These results show an area of potential occurrence for each species and only consider changes in the abiotic environment. Further geological and edaphic factors are not taken into account. This was partly because of the difficulty in obtaining geology and soil predictor layers, but was also because the available occurrence records were only available to a 15 minute resolution, and because the study was examining large-scale vegetation trends. However, the geology of the region is varied, with basaltic and sandstone geologies, but the effects of these on plant diversity are not known.

The effect of biotic interactions, species dispersal and evolution in affecting where species move during a climatic change are noted by Pearson and Dawson (2003). Biotic interactions may enable a species survive in a smaller region than its climatic niche, or move downslope rather than upslope (Lenoir et al., 2010). These models assume only migration to areas that become suitable in future and do not assume adaptive evolution allowing a species to remain in its current niche. Full dispersal and no dispersal assumptions have been made in our study, with the no dispersal assumption predicting greater contraction of the modelled species towards high elevation regions under future climate than the full dispersal assumption. Most of the species being modelled are known or suspected to be wind dispersed, with a few, such as the legumes Lotononis sericophylla and Indigofera burchellii, having exploding pods which drop their seeds in the vicinity of the parent plant. Wind dispersal is potentially long range dispersal (Nathan, 2006), and the majority of the modelled species use this method, leading to possible future distribution patterns which resemble the full 
dispersal assumption which assumes no lag between climate change and species distribution. Our projections suggest species range contraction, so the dispersal syndrome of the species being studied is less important than if a species shift were being projected.

\section{$\underline{\text { Implications }}$}

Biodiversity loss is one of the major potential impacts of changing montane land cover (Beniston, 2003). A smaller potential extent of occurrence, as the montane species' ranges of South Africa and Lesotho contract to a higher elevation, has serious biodiversity implications because these mountainous regions are home to high plant diversity and several centres of endemism. Our projections suggest a smaller potential area which is suitable for this plant diversity to occur. One of the reasons for high levels of endemism in different South African mountain ranges is because mountainous regions have acted as refugia in past climate changes (Medail and Diadema, 2009). Mountainous regions, owing to their topographical heterogeneity, allow the persistence of species in small, suitable microhabitats when climates change (Medail and Diadema, 2009). These species ranges expand and contract, as climate becomes more or less favourable, and speciation can occur (e.g. Bentley et al., 2014). The IUCN (2012) note a projected decline in range size as a key determinant for deciding on a species listing, making a projected range contraction of key importance when deciding on the vulnerability of species to extinction. The modelled responses of plants used in this study show a declining potential distribution as climate changes and therefore suggest potentially increased vulnerability. This is a cause for concern for these southern African regions which are high in biodiversity and endemism.

The region highlighted by our analyses as being the predicted area of montane refuge is centred in the Drakensberg Alpine Centre (DAC) of plant endemism. This area comprises the highlands of Lesotho (Maloti Mountains) and the KwaZulu-Natal and Eastern Cape Drakensberg of South Africa. The DAC hosts approximately 2800 species of flowering plants, $16 \%$ of which are endemic (Carbutt \& 
Edwards 2006), and spans two countries, each of which have vastly different land use and ownership practices.

The montane areas of Lesotho comprise communal rangelands, and a transhumance system of rotational grazing is applied (Quinlan and Morris, 1994). Concerns about land degradation in the Lesotho highlands were raised over 80 years ago (Staples and Hudson 1938), and this decline has been documented in a number of reports and other literature (e.g. McVean 1997; Turpie \& Forsythe (2014).

The threats to these high elevation ecosystems are varied, including land degradation as noted above, wind farms (Rushworth and Kruger, 2014), mining (Kleynhans 2016), increasingly easy access due to the tarring of roads (Kalwij et al. 2008; Carbutt 2012) and an extensive and ongoing series of dam building projects to ensure a constant supply of water to neighbouring South Africa (Waites 2000). Water provision is the most important ecosystem service provided by these mountains (Taylor et al. 2016), but activities associated with these large infrastructure projects is also enabling the expansion of alien invasive species (Kalwij et al. 2008; Carbutt 2012).

Within Lesotho there are only a few areas set aside for formal conservation. Tséhlanyane National Park, 5600 hectares in extent, was established by the Lesotho Highlands Water Commission and is relatively inaccessible but also geared towards ecotourism. Limited floristic diversity and other studies for the area have been published (Wybenga 2006; Letsela 2003). The much smaller Bokong Nature Reserve $\left(20 \mathrm{~km}^{2}\right)$ is one of the highest reserves in Africa, and has not been the site of much, if any, scientific study, and is next to a tarred road to the Katse Dam, and hence accessible to tourists.

The largest conservation area is the Sehlabathebe National Park, which was established in 1970 and is located on the border with South Africa. This reserve is $69.5 \mathrm{~km}^{2}$ in extent, and has been the focus of some biodiversity studies (e.g. Kopij, 2002; Lynch; 1990; Guillarmod 1977). This park forms part of the southern-most section of the Maluti Drakensberg Transfrontier Park (MDTP), and is also included 
in Peace parks Foundation world heritage list in 2013 (

http://www.peaceparks.co.za/news.php?pid=1264\&mid=1322\&lid=1004).

The MDTP was formalised in 2001 (Shroyer and Blignaut 2003), and is the largest montane biodiversity conservation area that falls within the area identified here as the potential climate refuge for the species modelled here. As noted above, the MDTP includes a number of reserves in both Lesotho and South Africa, the latter country contributing the uKhahlamba Drakensberg Park (UDP), which is also a World Heritage Site and a Ramsar Site and the Golden Gate Highlands National Park, managed by the South African National Parks agency (SANParks). There are also a number of parks and reserves under the management of Ezemvelo KZN Wildlife, a provincial conservation body in the province of KwaZulu-Natal.

While biodiversity monitoring plans for the MDTP have been proposed, (Hughes et al. 2007), the reality and complexities of the MDTP as a conservation area are various and varied (e.g. Crowson 2011). However, the opportunities for research are considerable, and the region must be considered in its entirety as a Social Ecological System (Grab \& Nusser 2001; Sandwith 2003). From a South African perspective, mountains and their management are well legislated by various acts and other legislation, but there is no formal unifying mountain management policy (Shroyer and Blignaut 2003).

Our results suggest that this mountain area, which is already a centre of plant endemism, will become a critical area for the conservation of montane plant (and by association animal) diversity in years to come under ongoing climate change. It is thus imperative that the governments of both South Africa and Lesotho engage in an urgent and meaningful manner alongside conservation bodies to ensure that these fragile ecosystems are protected and that the ecosystem services they provide (most importantly water) be protected and monitored. 


\section{References}

Barbet-Massin M, Jiguet F, Albert CH, Thuiller W (2012) Selecting pseudo-absences for species distribution models: how, where and how many? Methods in Ecology and Evolution 3:327-338.

Barry RG (2008) Mountain Weather and Climate. Cambridge University Press, UK.

Baselga A, Orme D, Villeger S, De Bortoli J, Lerieur F (2013) betapart: Partitioning beta diversity into turnover and nestedness components. R Foundation for Statistical Computing, Vienna.

Bellard C, Bertelsmeier C, Leadley P, Thuiller W, Courchamp F (2012) Impacts of climate change on the future of biodiversity. Ecology 15(4):365-377.

Beniston M (2003) Climatic change in mountain regions: A review of possible impacts. Climatic Change 59:5-31.

Bentley J, Verboom GA, Bergh NG (2014) Erosive processes after tectonic uplift stimulate vicariant and adaptive speciation: evolution in an Afrotemperate-endemic paper daisy genus. BMC Evolutionary Biology 14(27).

Birkenhauer J (1991) The Great Escarpment of Southern Africa and its Coastal Forelands - A Reappraisal. Geobuch-Verlag, Munich.

Bishop TR, Robertson MP, van Rensburg BJ, Parr CL (2015) Contrasting species and functional beta diversity in montane ant assemblages. Journal of Biogeography. 42(9):1776-1786.

Bivand R, Rundel C, Pebesma E, Stuetz R, Hufthammer KO (2016) rgeos: Interface to Geometry Engine - Open Source (GEOS). R Foundation for Statistical Computing, Vienna.

Buckland S, Cole NC, Aguirre-Gutierrez J, Gallagher LE, Henshaw SM, Besnard A, Tucker RM, Bachraz V, Rohumaun K, Harris S (2014) Ecological Effects of the Invasive Giant Madagascar Day Gecko on 
Endemic Mauritian Geckos: Applications of Binomial-Mixture and Species Distribution Models. Plos One 9(4):1-9.

Butchart SHM, Walpole M, Collen B, van Strien A, Scharlemann JPW, Almond RAE, Baillie JEM, Bomhard B, Brown C, Bruno J, Carpenter KE, Carr GM, Chanson J, Chenery AM, Csirke J, Davidson NC, Dentener F, Foster M, Galli A, Galloway JM, Genovesi P, Gregory RD, Hockings M, Kapos V, Lamarque JF, Leverington F, Loh J, McGeoch MA, McRae L, Minasyan A, Morcillo MH, Oldfield TEE, Pauly D, Quader S, Revenga C, Sauer JR, Skolnik B, Spear D, Stanwell-Smith D, Stuart SN, Symes A, Tierney M, Tyrrell TD, Vie JC, Watson R (2010) Global Biodiversity: Indicators of Recent Declines. Science 328(5982):1164-1168.

Carbutt C (2012) The emerging invasive alien plants of the Drakensberg Alpine Centre, southern Africa. Bothalia 42 (2): 71-85.

Carbutt C, Edwards TJ (2004) The flora of the Drakensberg Alpine Centre. Edinburgh Journal of Botany. 60(3):581-607.

Carbutt C, Edwards TJ (2006) The endemic and near-endemic angiosperms of the Drakensberg Alpine Centre. South African Journal of Botany 72 (1): 105-132.

Chefaoui RM, Lobo JM (2008) Assessing the effects of pseudo-absences on predictive distribution model performance. Ecological Modelling 210(4):478-486.

Chen IC, Hill JK, Ohlemuller R, Roy DB, Thomas CD (2011) Rapid Range Shifts of Species Associated with High Levels of Climate Warming. Science 333(6045):1024-1026.

Clark VR, Barker NP, Mucina L (2009) The Sneeuberg: A new centre of floristic endemism on the Great Escarpment, South Africa. South African Journal of Botany 75:196-238. 
Clark VR, Barker NP, Mucina L (2011a) Taking the Scenic route - the southern Great Escarpment (South Africa) as part of the Cape to Cairo florisitic highway. Plant Ecology and Diversity 4(4):313328.

Clark VR, Barker NP, Mucina L (2011b) A phytogeographic assessment of the Nuweveldberge, South Africa. South African Journal of Botany 77(1):147-159.

Clark VR, Barker NP, Mucina L (2011c) The Roggeveldberge - Notes on a botanically hot area on a cold corner of the southern Great Escarpment, South Africa. South African Journal of Botany 77(1):112-126.

Clark VR, Dold AP, McMaster C, McGregor G, Bredenkamp C, Barker NP (2014) Rich sister, poor cousin: Plant diversity and endemism in the Great Winterberg-Amatholes (Great Escarpment, Eastern Cape, South Africa). South African Journal of Botany 92:159- 174.

Cowling RM, Hilton-Taylor C (1997) Phytogeography, flora and endemism. In: Cowling RM, Richardson DM, Pierce SM (eds) Vegetation of Southern Africa. Cambridge University Press, Cambridge, pp. 43-61.

Crouch, NR (2011) Ferns of Southern Africa. Struik Nature.

Crowson JM (2011) Maloti Drakensberg Transfrontier Park Joint Management: Sehlabathebe National Park (Lesotho) and the uKhahlamba Drakensberg Park World Heritage Site (South Africa). Science and stewardship to protect and sustain wilderness values: Ninth World Wilderness Congress symposium. In: Watson A, Murrieta-Saldivar J, McBride B (eds). US Department of Agriculture, Forest Service, Rocky Mountain Research Station, November 6-13, 2009, pp. 53. Department of Environmental Affairs (2013) Long-Term Adaptation Scenarios Flagship Research Programme (LTAS) for South Africa. Climate Trends and Scenarios for South Africa, Pretoria. 
Devictor V, Van Swaay C, Brereton T, Brotons L, Chamberlain D, Heliölä J, Herrando S, Julliard R, Kuussaari M, Lindström Å, Reif J (2012) Differences in the climatic debts of birds and butterflies at a continental scale. Nature Climate Change 2: 121-124.

Elith J, Graham CH, Anderson RP, Dudik M, Ferrier S, Guisan A, Hijmans RJ, Huettmann F, Leathwick JR, Lehmann A, Li J, Lohmann LG, Loiselle BA, Manion G, Moritz C, Nakamura M, Nakazawa Y, Overton JM, Peterson AT, Phillips SJ, Richardson K, Scachetti-Pereira R, Schapire RE, Sobero'n J, Williams S, Wisz MS, Zimmermann, NE (2006) Novel methods improve prediction of species' distributions from occurrence data. Ecography 29:129-151.

Elith J, Kearney M, Phillips S (2010) The art of modelling range-shifting species. Methods in Ecology and Evolution 1(4):330-342.

Engelbrecht FA, Landman WA, Engelbrecht CJ, Landman S, Bopape MM, Roux B, McGregor JL, Thatcher M (2011) Multi-scale climate modelling over Southern Africa using a variable-resolution global model. Water SA 37(5):647-658.

Foden W, Potter L (2005b) Polygala gymnoclada [Homepage of Red List of South African Plants]. http://redlist.sanbi.org/species.php?species=3614-40. Accessed 22 June 2015.

Foden W, Potter L (2005a) Indigofera burchellii DC. [Homepage of Red List of South African Plants]. http://redlist.sanbi.org/species.php?species=357-64. Accessed 22 June 2015.

Foden W, Potter L (2011) Senecio asperulus [Homepage of Red List of South African Plants]. http://redlist.sanbi.org/species.php?species=3152-37. Accessed 22 June 2015.

Freeman E (2012) PresenceAbsence: Presence-Absence Model Evaluation. R Foundation for Statistical Computing, Vienna. 
Grab S, Nüsser M (2001) Towards an integrated research approach for the Drakensberg and Lesotho mountain environments: a case study from the Sani plateau region. South African Geographical Journal 83(1): 64-68.

Guillarmod AJ (1977) Rhodohypoxis in the Sehlabathebe Mountain National Park, Lesotho. Veld and Flora 63(3): 21.

Guisan A, Thuiller W (2005) Predicting species distribution: offering more than simple habitat models. Ecology Letters 8:993-1009.

Hadley KS, Price LW, Grabherr G (2013) Mountain Vegetation. In: Price MF, Byers AC, Friend DA, Kohler T, Price LW (eds) Mountain Geography. University of California Press, Los Angeles, pp. 183220.

Haensler A, Hagemann S, Daniela J (2011) The role of the simulation setup in a long-term highresolution climate change projection for the southern African region. Theoretical Applied Climatology 106:153-169.

Hijmans RJ, Phillips S, Leathwick J, Elith J (2015) dismo: Species Distribution Modeling. R Foundation for Statistical Computing, Vienna.

Hilliard OM, Burtt BL (1987) The botany of the southern Natal Drakensberg. National Botanic Gardens.

Hoare DB (n.d.) Tetrachne dregei Nees [Homepage of CIAT/FAO] http://www.fao.org/ag/agp/AGPC/doc/gbase/Safricadata/tetradre.htm. Accessed 22 June 2015 Hodd RL, Bourke D, Skeffington MC (2014) Projected Range Contractions of European Protected Oceanic Montane Plant Communities: Focus on Climate Change Impacts Is Essential for Their Future Conservation. Plos One 9(4):1-14. 
Hughes J, Benn G, Laros M (2007) Spatial Assessment of Biodiversity Priorities in the Lesotho Highlands: Executive Summary. Report for the maloti Drakensberg Transfrontier project.

Hyde MA, Wursten BT, Ballings P, Coates Palgrave M (2015a) Flora of Zimbabwe: Species information: Haplocarpha nervosa. [Homepage of Flora of Zimbabwe] http://www.zimbabweflora.co.zw/speciesdata/species.php?species id=161730. Accessed 22 June 2015.

Hyde MA, Wursten BT, Ballings P, Coates Palgrave M (2015b) Flora of Zimbabwe: Species information: Mohria nudiuscula. [Homepage of Flora of Zimbabwe] http://www.zimbabweflora.co.zw/speciesdata/species.php?species id=161730. Accessed 22 June 2015.

Ihlow F, Bonke R, Hartmann T, Geissler P, Behler N, Rodder D (2014) Habitat suitability, coverage by protected areas and population connectivity for the Siamese crocodile Crocodylus siamensis Schneider, 1801. Aquatic Conservation: Marine and Freshwater Ecosystems 25(4):544-554. IPCC (2014) Climate Change 2014: Synthesis Report. Contribution of Working Groups I, II and III to the Fifth Assessment Report of the Intergovernmental Panel on Climate Change [Core Writing Team, R.K. Pachauri and L.A. Meyer (eds.)]. IPCC, Geneva.

IUCN (2012) IUCN Red List Categories and Criteria: Version 3.1. IUCN, Gland and Cambridge.

Keppel G, Van Niel KP, Wardell-Johnson GW, Yates CJ, Byrne M, Mucina L, Schut AGT, Hopper SD, Franklin SE (2012) Refugia: identifying and understanding safe 22 havens for biodiversity under climate change. Global Ecology and Biogeography 21:393-404.

Kleinhans M (2016) Moving mountains: commodity: diamonds \& gems moving. Inside Mining 9(6): $10-11$.

Kopij G (2002) The birds of Sehlabathebe National Park, Lesotho. Koedoe 45(1) 65-78. 
Koppen W (1936) Das geographische System der Klimate. In: Koppen W, Geiger R (eds) Handbuch der Klimatologie. Verlag von Gebru"der Borntraeger, Berlin, pp. 1-44.

Lawrence E (2002) Pelargonium zonale [Homepage of Plantzafrica].

http://www.plantzafrica.com/plantnop/pelargzonale.htm. Accessed 22 June 2015.

Lenoir J, Gegout J, Guisan A, Vittoz P, Wohlgemuth T, Zimmermann NE, Dullinger S, Pauli H, Willner W Svenning J (2010) Going against the flow: potential mechanisms for unexpected downslope range shifts in a warmer climate. Ecography (33):295-303.

Letšela T, Witkowski ETF, Balkwill K (2003) Plant resources used for subsistence in Tsehlanyane and Bokong in Lesotho. Economic Botany 57(4): 619-639.

Lobo JM, Jimenez-Valverde A, Real R (2008) AUC: a misleading measure of the performance of predictive distribution models. Global Ecology and Biogeography 17:145-151.

Lynch JP (1990) The mammals of Sehlabathebe National Park, Lesotho. Researches of the National Museum Bloemfontein 6(12).

MacArthur RH (1972) Geographical Ecology: Patterns in the Distribution of Species. Princeton University Press, Princeton.

Marnewick MD, Retief EF, Theron NT, Wright DR, Anderson TA (2015) Important Bird and Biodiversity Areas of South Africa. Johannesburg: BirdLife South Africa

Matthews WS, van Wyk AE, Bredenkamp GJ (1993) Endemic flora of the north-eastern Transvaal Escarpment, South Africa. Biological Conservation 63(1):83-94.

McCain CM, Grytnes JA (2010) Elevational Gradients in Species Richness. Encyclopedia of Life Sciences.

McVean DN (1977). Nature conservation in Lesotho. 
McCarthy T, Rubidge B (2005) The Story of Earth and Life. Struik, Cape Town.

Medail F, Diadema K (2009) Glacial refugia influence plant diversity patterns in the Meditterranean Basin. Journal of Biogeography 36:1333-1345.

Nathan R (2006) Long-Distance Dispersal of Plants. Science 313:786-788.

Nel W (2009) Rainfall trends in the KwaZulu-Natal Drakensberg region of South Africa during the twentieth century. International Journal of Climatology 29(11):1634-1641.

Nägele KL, Hausdorf B (2015) Comparative phylogeography of land snail species in mountain refugia in the European Southern Alps. Journal of Biogeography 42(5):821-832.

Notten A (2009) Euryops annae [Homepage of Plantzafrica]

http://www.plantzafrica.com/plantefg/euryopsannae.htm. Accessed 22 June 2015.

Ollier CD (1985) Morphotectonics of continental margins with great escarpments. In: Morisawa M, Hack JT (eds.) Tectonic Geomorphology. Allen and Unwin, Boston.

Parmesan C (2006) Ecological and Evolutionary Responses to Recent Climate Change. Annual Review of Ecology, Evolution, and Systematics 37:637-669.

Parmesan C, Yohe G (2003) A globally coherent fingerprint of climate change impacts across natural systems. Nature 421:37-42.

Partridge TC, Maud RR (1987) Regional geomorphic evidence for climatic change in southern Africa since the Mesozoic. Palaeoecol Afr. 18: 337-345.

Pearson RG, Dawson TP (2003) Predicting the impacts of climate change on the distribution of species: are bioclimate envelope models useful? Global Ecology and Biogeography 12:361-371.

Pepin N, Bradley RS, Diaz HF, Baraer M, Caceres EB, Forsythe N, Fowler H, Greenwood G, Hashmi, MZ, Liu XD, Miller JR, Ning L, Ohmura A, Palazzi E, Rangwala I, Schoner W, Severskiy I, Shahgedanova 
M, Wang MB, Williamson SN, Yang DQ (2015) Elevation-dependent warming in mountain regions of the world. Nature Climate Change 5:424-430.

Peters RL, Darling JDS (1985) The Greenhouse Effect and Nature Reserves. BioScience 35(11):707717.

Platts PJ, Gereau RE, Burger ND, Marchant R (2013) Spatial heterogeneity of climate change in an Afromontane centre of endemism. Ecography 36:518-530.

Pooley E (2003) Mountains Flowers: A Field Guide to the Flora of Drakensberg and Lesotho. Flora Publications Trust, Durban.

Pooley E (2005) A Field Guide to Wild Flowers of Kwazulu-Natal and the Eastern Region, 2nd edn. Natal Flora Publications Trust, Durban.

Quinlan T, Morris CD (1994) Implications of changes to the transhumance system for conservation of the mountain catchments in eastern Lesotho. African Journal of Range and Forage Science 11 (3) 7681.

R core team (2015) R: A language and environment for statistical computing. R Foundation for Statistical Computing, Vienna.

Robertson MP, Visser V, Hui C (2016) Biogeo: an R package for assessing and improving data quality of occurrence record datasets. Ecography 39(4):394-401.

Rushworth I, Krüger S (2014) Wind farms threaten southern Africa's cliff-nesting vultures. Ostrich, 85 (1):13-23.

SANBI (2009) PRECIS Information Database [Homepage of SANBI] http://posa.sanbi.org/intro precis.php. Accessed 17 March 2017. 
Sandwith T. (2003) Overcoming barriers: conservation and development in the Maloti-Drakensberg Mountains of Southern Africa. Journal of Sustainable Forestry 17 (1-2): 149-169.

Schonswetter P, Stehlik I, Holderegger R, Tribsch A 2005 Molecular evidence for glacial refugia of mountain plants in the European Alps. Molecular Ecology 14(11):3547-3555.

Shroyer ME, Blignaut P (2003) Mountain conservation in South Africa. USDA Forest Service Proceedings RMRS-P-27, pp. 26-33.

Staples RR, Hudson WK (1938) An ecological survey of the mountain area of Basutoland. Crown Agents, London.

Taylor SJ, Ferguson JWH, Engelbrecht FA, Clark VR, Van Rensburg S, Barker, N (2016) The Drakensberg Escarpment as the Great Supplier of Water to South Africa. In: Greenwood GB, Shroder Jr JF (eds) Mountain Ice and Water: Investigations of the Hydrologic Cycle in Alpine Environments. Elsevier, Oxford, Cambridge, Amsterdam, pp. 1-46.

Thuiller W, Georges D, Engler R (2014) biomod2: Ensemble platform for species distribution modelling. R Foundation for Statistical Computing, Vienna.

Turpie J, Forsythe K (Eds) (2014) State of the Mohales Dam Catchment . Volume 2. Specialist studies on Land Cover, Flora and Wetlands.

Vorsino AE, Fortini LB, Amidon FA, Miller SE, Jacobi JD, Price JP, Gon III SA, Koob, G.A. (2014) Modeling Hawaiian Ecosystem Degradation due to Invasive Plants under Current and Future Climates. Plos One 9(5):1-18.

Waites B (2000) The Lesotho Highlands Water Project. , Geography: Journal of the Geographical Association, vol. 85, no. 4, pp. 369-374. 
Wang B, Jiang J, Xie F, Li C (2013) Phylogeographic Patterns of mtDNA Variation Revealed Multiple Glacial Refugia for the Frog Species Feirana taihangnica Endemic to the Qinling Mountains. Journal of Molecular Evolution 76(3):112-128.

Webber BL, Yates CJ, Le Maitre DC, Scott JK, Kriticos DJ, Ota N, McNeill A, Le Roux JJ Midgley, G.F (2011) Modelling horses for novel climate courses: insights from projecting potential distributions of native and alien Australian acacias with correlative and mechanistic models. Diversity and Distributions 17:978-1000.

White F (1983) The Vegetation of Africa. UNESCO, Paris.

Woodward FI (1987) Climate and Plant Distribution. Cambridge University Press, Cambridge. 
Appendix 1: Previous studies showing the influence of climate change on the geographic distribution of biodiversity in mountains. The codes under "Study Type" indicate that the study was either based on modelling approaches (M) or surveys (S).

\begin{tabular}{|c|c|c|c|c|}
\hline $\begin{array}{l}\text { Country /region and } \\
\text { mountain region studied }\end{array}$ & Methods used & Vegetation response to climate change & Reference for the study & Type \\
\hline Andes in South America & $\begin{array}{l}\text { Model including migration rates, } \\
\text { population density distributions } \\
\text { and human land-use. }\end{array}$ & $\begin{array}{l}\text { Most species expected to undergo a population } \\
\text { decline. }\end{array}$ & Feeley and Silman, 2010 & $\mathrm{M}$ \\
\hline Alps in Europe & $\begin{array}{l}\text { Niche model projecting future } \\
\text { ranges of } 150 \text { species including } \\
\text { models of species demography and } \\
\text { seed dispersal. }\end{array}$ & $\begin{array}{l}\text { Range size reductions of } 44 \text { to } 50 \% \text { by end of } 21^{\text {st }} \\
\text { century. Potential lag as } 40 \% \text { of flora may be living } \\
\text { in unsuitable regions. }\end{array}$ & Dullinger et al., 2012 & $\mathrm{M}$ \\
\hline Alps in Europe & $\begin{array}{l}\text { Niche modelling climate change } \\
\text { projections on } 2632 \text { plant species } \\
\text { using five modelling algorithms and } \\
\text { the modelling package biomod. }\end{array}$ & $\begin{array}{l}36-55 \% \text { alpine species, } 31-51 \% \text { of subalpine } \\
\text { species and } 19-46 \% \text { of montane species may lose } \\
\text { more than } 80 \% \text { of suitable habitat by } 2070 \text { to } \\
2100 \text {. }\end{array}$ & Engler et al., 2011 & M \\
\hline $\begin{array}{l}\text { Santa Calina Mountains in } \\
\text { southern Arizona }\end{array}$ & $\begin{array}{l}\text { Re-examining of previously } \\
\text { sampled plant transects. }\end{array}$ & $\begin{array}{l}\text { Large changes in the elevational ranges of } \\
\text { montane plants with significant overall upward } \\
\text { movement in the lower elevational boundaries } \\
\text { have occurred. }\end{array}$ & Brusca et al., 2013 & $\mathrm{~S}$ \\
\hline Mountains in Taiwan & $\begin{array}{l}\text { Resurvey data of the period } 1906 \\
\text { to } 2006 .\end{array}$ & $\begin{array}{l}\text { Upper altitudinal limits of species have risen } \\
\text { around } 3.6 \mathrm{~m} / \text { year }\end{array}$ & Jump et al., 2011 & $\mathrm{~S}$ \\
\hline Andes in South America & $\begin{array}{l}\text { Usage of repeated data from } \\
\text { vegetation census between } \\
2003 / 2004 \text { to } 2007 / 2008\end{array}$ & $\begin{array}{l}\text { Most tropical Andean tree genera shifted their } \\
\text { mean distributions upslope over the study period } \\
\text { at a mean rate of migration of approximately } 2.5 \text { - } \\
3.5 \text { vertical metres upslope per year. }\end{array}$ & Feeley et al., 2011 & $\mathrm{~S}$ \\
\hline Alps in Austria & $\begin{array}{l}\text { Climate projections showing the } \\
\text { influence of climate change on } \\
\text { biodiversity. }\end{array}$ & $\begin{array}{l}77 \% \text { habitat loss for the areas of endemism of five } \\
\text { taxonomic groups (vascular plants, snails, spiders, } \\
\text { butterflies and beetles). }\end{array}$ & Dirnbock et al., 2011 & M \\
\hline $\begin{array}{l}\text { Santa Rosa Mountains in } \\
\text { southern California }\end{array}$ & $\begin{array}{l}\text { A comparison of plant cover } \\
\text { surveys in } 1977 \text { versus 2006/2007. }\end{array}$ & $\begin{array}{l}\text { Elevation of the dominant plant species rose by } 65 \\
\mathrm{~m} \text { between the surveys. }\end{array}$ & Kelly and Goulden, 2008 & $\mathrm{~S}$ \\
\hline Scandes in Sweden & Tree species surveys. & Tree-limit advance by greater than $100 \mathrm{~m}$. & Kullman, 2001 & $\mathrm{~S}$ \\
\hline Norwegian Mountains & $\begin{array}{l}\text { Resurveyed sites between 1930/31 } \\
\text { and } 1998 .\end{array}$ & $\begin{array}{l}\text { Lowland species, dwarf shrubs, and species with } \\
\text { wide altitudinal and ecological ranges showed the } \\
\text { greatest increases in abundance and the greatest } \\
\text { altitudinal advances. }\end{array}$ & $\begin{array}{l}\text { Klanderud and Birks, } \\
2002\end{array}$ & $\mathrm{~S}$ \\
\hline Mountains of Costa Rica & $\begin{array}{l}\text { Bird surveys between } 1979 \text { and } \\
1998 .\end{array}$ & Elevational rise in birds to higher elevation. & Pounds et al., 1999 & $\mathrm{~S}$ \\
\hline Alps in Europe & $\begin{array}{l}\text { Revisiting sites across the Alps in } \\
\text { continual montoring. }\end{array}$ & Species have moved upslope on average. & Pauli et al., 2012 & $\mathrm{~S}$ \\
\hline Global mountain ranges & $\begin{array}{l}\text { Treeline data from } 166 \text { sites for } \\
\text { which treeline dynamics had been } \\
\text { recorded since } 1900 \text { AD. }\end{array}$ & Majority of sites have treelines moving upslope. & Harsh et al., 2009 & $\mathrm{~S}$ \\
\hline
\end{tabular}




\section{$\underline{\text { References: }}$}

Brusca RC, Wiens JF, Meyer WM, Eble J, Franklin K, Overpeck JT, Moore W (2013) Dramatic response to climate change in the Southwest: Robert Whittaker's 1963 Arizona Mountain plant transect revisited. Ecology and Evolution 3(10):3307-3319.

Dirnbock T, EssI F, Rabitsch W (2011) Disproportional risk for habitat loss of high-altitude endemic species under climate change. Global Change Biology 17(2):990-996.

Dullinger S, Gattringer A, Thuiller W, Moser D, Zimmermann NE, Guisan A, Willner W, Plutzar C, Leitner M, Mang T, Caccianiga M, Dirnbock T, Ertl S, Fischer A, Lenoir J, Svenning JC, Psomas A, Schmatz DR, Silc U, Vittoz P, Hulber K (2012) Extinction debt of high-mountain plants under twentyfirst-century climate change. Nature Climate Change 2:619-622.

Engler R, Randin CF, Thuiller W, Dullinger S, Zimmermann NE, Araújo MB, Pearman PB, Le Lay G, Piedallu C, Albert CH, Choler, P (2011) 21st century climate change threatens mountain flora unequally across Europe. Global Change Biology 17(7):2330-2341.

Feeley KJ, Silman MR (2010) Land-use and climate change effects on population size and extinction risk of Andean plants. Global Change Biology 16(12):3215-3222.

Feeley KJ, Silman MR, Bush MB, Farfan W, Cabrera KC, Malhi Y, Meir P, Revilla NS, Quisiyupanqui MNR, Saatchi S (2011) Upslope migration of Andean trees. Journal of Biogeography 38 (4):783-791.

Harsh MA, Hulme PE, McGlone MS, Duncan RP (2009) Are treelines advancing? A global metaanalysis of treeline response to climate warming. Ecology Letters 12(10):1040-1049.

Jump AS, Huang TJ, Chou CH (2011) Rapid altitudinal migration of mountain plants in Taiwan and its implications for high altitude biodiversity. Ecography 35(3):204- 210.

Kelly AE, Goulden ML (2008) Rapid shifts in plant distribution with recent climate change. PNAS 105(33):11823-11826.

Klanderud K, Birks HJB (2003) Recent increases in species richness and shifts in altitudinal distributions of Norwegian mountain plants. The Holocene 13(1):1-6.

Kullman L (2001) 20th century climate warming and tree-limit rise in the southern Scandes of Sweden. Ambio 30(2):72-80.

Pauli H, Gottfried M, Dullinger S, Abdaladze O, Akhalkatsi M, Alonso JLB, Coldea G, Dick J, Erschbamer B, Calzado RF, Ghosn D, Holten JI, Kanka R, Kazakis G, Kollár J, Larsson P, Moiseev P, Moiseev D, Molau U, Mesa JM, Nagy L, Pelino G, Puşcaş M, Rossi G, Stanisci A, Syverhuset AO, Theurillat JP, Tomaselli M, Unterluggauer P, Villar L, Vittoz P, Grabherr G (2012) Recent Plant Diversity Changes on Europe's Mountain Summits. Science 336(6079):353-355.

Pounds JA, Fogden MPL, Campbell JH (1999) Biological response to climate change on a tropical mountain. Nature 398:611-615. 